\title{
AKTIVITAS MEDIA RELATIONS HUMAS SETDA KOTA SALATIGA DALAM MEMBENTUK BERITA POSITIF
}

\author{
Nugrahaning Esa Pratiwi, Richard Gordon Mayopu, dan George Nicholas Huwae
}

Program Studi Public Relations, Fakultas Teknologi Informasi Universitas Kristen Satya

Wacana, Jl. Diponegoro No. 52-60, Salatiga, Jawa Tengah, No Telp. (0298) 321212

Email: 602013604@student.uksw.edu, richard.mayopu@staff.uksw.edu, nicholas.huwae@staff.uksw.edu

\begin{abstract}
This research aims to find out the role of media relations in forming positive news on printed media by having a special page for Salatiga news as research focus. This research is a qualitative research by using qualitative descriptive approach. Observation, interview, document collection and photo activities are used to collect data. The result indicates that informal media relations activities are more effective to create positive news about Salatiga government in printed media because it can build good relation between Public Relations practitioners and journalists.
\end{abstract}

Key Words: Media Relations Activities, Positive News, Printed Media

\begin{abstract}
Abstrak
Penelitian dilakukan untuk mengetahui peran aktivitas media relations dalam membentuk berita positif di media cetak dengan menjadikan suratkabar yang memiliki halaman khusus untuk berita Salatiga sebagai fokus penelitian. Penelitian menggunakan pendekatan deskriptif kualitatif yang menjadikan observasi, wawancara, pengumpulan dokumen dan foto sebagai teknik pengumpulan data. Hasil penelitian ini menunjukkan aktivitas media relations informal lebih berperan dalam membentuk berita positif tentang pemerintahan Kota Salatiga di media cetak karena dapat menciptakan hubungan baik antara humas dan jurnalis.
\end{abstract}

Kata Kunci : Aktifitas Media Relations, Berita Positif, Media Cetak

\section{Pendahuluan}

Salatiga merupakan nama sebuah kota kecil yang berada di wilayah provinsi Jawa Tengah. Berdasarkan kesadaran bersama dan didorong kebutuhan areal pembangunan demi pengembangan daerah, muncul gagasan mengadakan pemekaran wilayah. Perluasan wilayah Kota Salatiga tentu memerlukan pengelolaan yang baik agar dapat menambah kemajuan kota Salatiga. Oleh karena itu dibentuk Satuan Kerja Pemerintah Daerah (SKPD) beserta Tata Kerjanya. Pemerintah juga menyadari akan pentingnya membentuk relasi yang baik dengan para stakeholderyaitu kelompok, atau organisasi yang berada di luar kendali anda yang berkecimpung di dalam proyek anda. Hampir semua stakeholder akan menyediakan layanan (pemenuhan permintaan, keahlian, peralatan, dan lain-lain) ke proyek anda, menerima layanan (data, fungsi, dan lainlain), atau memiliki hubungan dua arah (Thomsett, 2006). Para stakeholder dapat berasal dari dalam perusahaan atau dari perusahaan lain untuk membentuk citra positif Pemerintah secara khusus dan Kota Salatiga secara umum.

Sebagai upaya memenuhi kebutuhan pemerintah terhadap relasi yang baik dengan stakeholder maka dibentuklah Bagian Hubungan Masyarakat yang berada dibawah Sekretariat. Stakeholder Bagian Humas Setda Kota Salatiga yang diteliti pada penelitian kali ini hanya 
berfokus pada instansi media yaitu stakeholder yang mampu membantu humas dalam mensosialisasikan program kerja Pemerintah kepada stakeholder Pemerintah yang lain terutama kepada masyarakat. Humas sebagai corong Pemerintah perlu melakukan upaya untuk menjalin relasi yang baik lebih dulu dengan media atau yang biasa disebut dengan istilah media relations.

Menurut hasil wawancara yang dilakukan peneliti dengan Kabag Bagian Humas Setda Kota Salatiga, Bapak Adi Setiarso, S.E didapat pernyataan bahwa hubungan humas dan media semakin hari semakin baik. Hubungan yang semakin baik juga diikuti dengan berita positif mengenai Kota Salatiga dan Pemerintah yang memiliki jumlah lebih banyak daripada berita negatifnya dalam setiap bulan.Secara lebih jelas, pemberitaan tentang Kota Salatiga dan pemerintahannya dapat dilihat pada media cetak terutama pada media cetak surat kabar yang memiliki halaman khusus untuk berita seputar Kota Salatiga.

Sesuai data analisis media yang dibuat oleh sub-bagian analisis kemitraan media pada Bagian Humas Setda Kota Salatiga, jumlah berita mengenai Kota Salatiga yang meliputi segala kejadian baik di masyarakat maupun di pemerintahan selama 5 bulan mulai MeiSeptember 2014 yang disajikan melalui media cetak dapat dilihat pada tabel 1 . Hubungan baik antara Humas Setda Kota Salatiga dan jurnalis media kontributor Kota Salatiga juga terlihat dengan tidak di blow-up $\neg$ nya kasus mengenai sengketa tanah di Salatiga oleh media. Oleh karena itu, peneliti menganggap perlu untuk mengungkap dan mengetahui aktifitas media relations yang dilakukan Humas Setda Kota Salatiga kepada jurnalis media kontributor Kota Salatiga (jurnalis yang mendapatkan tugas untuk mencari beritaberita seputar Salatiga) serta peranannya
Tabel 1. Jumlah Berita Kota Salatiga di Media Cetak

\begin{tabular}{cccc}
\hline Bulan Berita & Berita (+) & Berita (-) & $\begin{array}{c}\text { Jumlah } \\
\text { Berita }\end{array}$ \\
\hline Mei 2014 & 243 & 128 & 371 \\
Juni 2014 & 268 & 107 & 375 \\
Juli 2014 & 233 & 73 & 306 \\
Agustus 2014 & 273 & 102 & 375 \\
September & 218 & 138 & 356 \\
2014 & & & \\
\hline
\end{tabular}

dalam membentuk berita positif di media cetak yang dituangkan dalam judul penelitian yaitu "Peran Aktifitas Media Relations dalam Membentuk Berita Positif di Media Cetak". Penelitian ini dilaksanakan dengan melihat keterlibatan antara Humas Setda Kota Salatiga dan jurnalis media cetak dalam aktifitas media relations yang diadakan oleh Bagian Humas Setda kota Salatiga.

Dari Sudut Pandang Praktisi Humas Kementerian dan Wartawan (Studi Kasus : Media relations di Kementerian Pendidikan dan Kebudayaan Republik Indonesia dalam rangka sosialisasi program dan kebijakan kementerian)" (Yunita, 2012). Penelitian ini mengungkap bahwa Kemendikbud melakukan sosialisasi program dan kebijakan dengan menggunakan beberapa saluran media yaitu media cetak, media elektronik, media luar ruang, media tatap muka, media kemitraan, pengumpulan dan pengolahan informasi pendidikan dan kebudayaan, dokumentasi foto/ audiovisual dan pengembangan mutu SDM. Hasil penelitian menyimpulkan bahwa banyaknyakegiatan Kemendikbud dengan menggunakan saluran media ternyata belum diikuti dengan pemahaman humas Kemendikbud mengenai makna dan maksud media relations sehingga Humas Kemendikbud bisa dikatakan belum mampu menjalankan tugas sebagai perwakilan Kemendikbud terutama sebagai sumber informasi utama bagi wartawan di lingkungan Kemendikbud.

Penelitian lain berjudul "Strategi Media Relations dalam Pemerintahan 
Daerah (Studi Deskriptif Kualitatif tentang Strategi Media Relations Bagian Humas dan Protokol Pemerintah Kota Surakarta dalam Menjalin Hubungan dengan Media Untuk Meningkatkan Citra Positif di Masyarakat Kota Surakarta)" (Prasetyo, 2010). Penelitian ini mengungkap proses strategi media relations yang dilakukan oleh Bagian Humas dan Protokol Pemkot Surakarta yaitu menggunakan media audio, media visual dan penggabungan kedua media tersebut yaitu audio-visual. Hasil penelitian ini menyimpulkan bahwa citra Kota Surakarta cukup kurang dan meski dapat mengakomodir kebutuhan wartawan terhadap informasi, namun pencitraan Humas dan Protokol kurang ada, yang ada hanyalah pencitraan Walikota.

Kedua penelitian terdahulu diatas memiliki persamaan yaitu samasama mencoba mengetahui bentuk media relations yang dilaksanakan bagian Humas Pemerintah. Sedangkan perbedaannya yaitu jika pada penelitian pertama mengacu pada pelaksanaan media relations untuk mensosialisasikan program dan kebijakan, penelitian kali ini berfokus pada peran pelaksanaan media relations dan jika penelitian kedua dilakukan untuk mengukur citra pemerintah melalui relasi dengan media massa, penelitian kali ini mencoba mengetahui proses dibalik pembentukan citra yaitu melalui pemberitaan di media cetak khususnya media cetak yang memiliki halaman khusus untuk berita tentang Kota Salatiga yang nantinya dapat menghasilkan data mengenai peran aktifitas media relations dalam membentuk berita positif di media cetak. Dalam melaksanakan fungsi kehumasan ini, aktifitas dilaksanakan oleh bagian humas atau dikenal dengan istilah public relations (PR) karena PR berperan sebagai "jembatan" antara perusahaan atau organisasi dengan publiknya, terutama tercapainya mutual understanding (saling pengertian) antara perusahaan dengan publiknya. Kini praktek PR memunculkan berbagai macam-macam PR, antara lain PR Pemerintahan, PR Industri dan Bisnis, PR Sosial, dan PR Internasional (Ardianto, 2009).

Dalam prakteknya, penerapan PR antara organisasi profit dengan lembaga pemerintahan memiliki perbedaan. PR atau humas pemerintah pada dasarnya tidak bersifat politis, PR Pemerintahan dibentuk untuk mempublikasikan atau mempromosikan kebijakan-kebijakan pemerintahan, memberi informasi secara teratur tentang kebijakan, rencana-rencana tentang peraturan dan perundangundangan, dan segala sesuatunya yang berpengaruh kepada kehidupan masyarakat (Ardianto, 2009). Humas instansi pemerintahan yang memiliki karakteristik yang berbeda dibandingkan humas pada umumnya, membutuhkan dasar hukum yang jelas dalam menjalankan tugas pokok dan fungsinya. Terlebih, efek dari kinerja humas instansi pemerintah sangat luas dan tidak terbatas kepada sekelompok publik tertentu (Wahyu Nilla Sari, 2012).

Pelaksanaan kehumasan lembaga pemerintahan, Bagian Humas Setda Kota Salatiga yang secara langsung melayani dan berhubungan dengan media tidak dapat hanya diam saja menikmati hubungan yang telah terjalin. Oleh karena itu, Humas Setda Kota Salatiga perlu melaksanakan aktifitas media relations sebagai usaha untuk mencapai publikasi atau penyiaran yang maksimum atas suatu pesan atau informasi humas dalam rangka menciptakan pengetahuan dan pemahaman bagi khalayak dari organisasi atau perusahaan yang bersangkutan (Jefkins, 1992). Beberapa cara yang dapat dijadikan alat melakukan hubungan pers (media relations) antara lain newsletter, acara khusus, press tour, 
laporan tahunan, pensponsoran, poster, iklan, pengumpulan uang, seminar dan program latihan, majalah dinding serta pameran. Selain itu, ada beberapa acara pers yang dapat dilakukan oleh praktisi Humas yaitu konferensi pers (press conference), kunjungan pers (facility visit) dan resepsi pers (press reception) (Syaifullah, 2004). Bentuk aktifitas media relations bermacam-macam sesuai dengan tujuan masing-masing organisasi atau perusahaan.

Pelaksanaan kegiatan media relations menempati posisi penting dalam pekerjaan seorang public relations karena media massa menjadi penjaga gawang (gatekeepers) dan mengontrol informasi yang mengalir ke masyarakat dalam suatu sistem sosial (Darmastuti, 2012). Hal itu sudah sejak lama disadari bahwa pers memiliki peranan yang besar dalam kehidupan sebuah lembaga, terlebih bagi lembaga yang selalu haus akanpengakuan masyarakat. Bagi lembaga pemerintahan pun, untuk meningkatkan citra positif membutuhkan pula peranan media massa ini. Sebab sebuah keberhasilan tanpa diketahui masyarakat merupakan suatu kegiatan yang sia-sia (Abdullah, 2004). Media relations hanyalah salah satu bagian dari public relations, namun bisa menjadi perangkat yang sangat penting dan efisien. Begitu kita bisa menyusun pesan yang bukan saja diterima, tetapi juga dipandang penting oleh media lokal, maka kita sudah membuat langkah besar menuju keberhasilan program kita (Iriantara, 2005).

Dengan hubungan baik yang terbentuk antara Humas Setda Kota Salatiga dan jurnalis media kontributor Kota Salatiga, nyatanya diikuti oleh jumlah berita positif tentang Salatiga yang jumlahnya lebih banyak dari berita negatif pada setiap bulannya. Berita yang disajikan merupakan realitas simbolik, realitas yang terdiri dari kata-kata yang membentuk kalimat, yang tersusun sistematis, terstruktur (Mursito, 2013). Dalam Kamus Besar Bahasa Indonesia (KBBI), berita diartikan sebagai keterangan mengenai kejadian atau peristiwa yang hangat; laporan sedangkan kata positif berarti bersifat nyata dan membangun sehingga dari urian diatas dapat disimpulkan bahwa definisi berita positif adalah laporan tentang suatu kejadian yang hangat, yang ditulis di media massa serta bersifat nyata dan membangun. Sedangkan menurut penuturan salah satu staf subbagian Analisis Kemitraan Media (AKM), Humas Setda Kota Salatiga, Lukman Fahmi, S.H.I., realitas maupun keterangan kejadian dianggap bukan berita buruk bagi Pemerintah Kota Salatiga jika berita tidak menyebabkan pandangan buruk atau menurunkan kepercayaan masyarakat terhadap pemerintah seperti berita yang tidak mendiskreditkan pemerintah. Sehingga berita positif bagi pemerintahan, jika dilandasi dengan konsep berita buruk diatas dapat diartikan sebagai berita yang menyebabkan pandangan baik atau meningkatkan kepercayaan masyarakat terhadap pemerintah.

Berita-berita tentang Pemerintah Kota Salatiga kemudian dimuat di media massa yang secara lebih jelas dapat dilihat dalam media massa cetak yaitu surat kabar terutama yang memiliki halaman khusus untuk berita tentang Salatiga. Surat kabar merupakan media cetak dengan format broadsheet. Secara garis besar, media cetak terdiri dari fakta dan opini sedangkan isi media cetak berdasarkan fakta adalah berita (Abdullah, 2004). Berita yang dimuat dalam surat kabar dapat memenuhi kebutuhan pemerintah terhadap pembentukan citra yang baik sebagai upaya agar pemerintah dapat tetap hidup dan orang-orang di dalamnya terus mengembangkan kreativitas bahkan memberikan manfaat yang lebih berarti bagi orang lain (Kasali, 2003). 


\section{Metode Penelitian}

Penelitian ini merupakan jenis penelitian deskriptif kualitatif yang bersifat melukiskan realitas sosial yang kompleks yang ada di masyarakat (Mantra Bagoes, 2004). Unit amatan dalam penelitian ini adalah Humas Setda Kota Salatiga dengan unit analisa yaitu aktifitas media relations yang dilakukan oleh Humas Setda Kota Salatiga. Data dikumpulkan dengan teknik observasi lapangan dan wawancara yang menjadi data primer serta didukung dengan dokumen berupa berita tentang Salatiga pada 4 surat kabar serta foto kegiatan media relations Humas Setda Kota Salatiga yang menjadi data sekunder. Sumber informasi pada penelitian ini adalah pegawai Humas Setda Kota Salatiga, jurnalis media cetak surat kabar kontributor Kota Salatiga yaitu jurnalis Jateng Pos, Jawa Pos, Suara Merdeka dan Wawasan dimana surat kabar tersebut memiliki halaman khusus untuk beritaberita tentang Kota Salatiga serta Kepala Kelurahan Kalicacing.

Teknik analisis data pada penelitian ini adalah analisis interaktif yang terdiri dari 3 langkah yaitu reduksi, model data (data display) dan penarikan atau verifikasi kesimpulan sebagai langkah terakhir (Ardianto, 2010). Dalam menganalisa dokumen berupa berita tentang Salatiga pada 4surat kabar sebagai data pendukung penelitian, dilakukan teknik analisis isi yaitu teknik sistematik untuk menganalisis isi pesan dan mengolah pesan, atau alat untuk mengobservasi dan menganalisis isi perilaku komunikasi yang terbuka dari komunikator yang dipilih. Analisis isi dapat digunakan untuk menganalisis semua bentuk komunikasi yang salah satunya adalah surat kabar (Ardianto, 2010).

Sebagai validitas data, triangulasi yaitu melihat situasi dari berbagai sudut pandang atau perspektif, dari berbagai segi sehingga lebih kredibel dan akurat (Suparno, 2008). Penelitian ini menggunakan triangulasi sumber data yaitu triangulasi yang dilakukan dengan membandingkan dan mengecek baik derajat kepercayaan suatu informasi yang diperoleh melalui waktu dan cara yang berbeda. Hasil dari perbandingan yang diharapkan adalah berupa kesamaan atau alasan-alasan terjadinya perbedaan (Bungin, 2010).

\section{Hasil dan Pembahasan}

Dalamsebuahlembagapemerintahan, bagian humas atau public relations (PR) memiliki peranan yang sangat penting. Pentingnya peranan humas telah ditangkap oleh Pemerintah Kota Salatiga yang kemudian menempatkan bagian Humas sebagai jembatan antara organisasi dengan publiknya, terutama tercapainya mutual understanding (saling pengertian) antara organisasi dengan publiknya. Humas pemerintah pada dasarnya tidak bersifat politis, humas pemerintahan dibentuk untuk mempublikasikan atau mempromosikan kebijakan-kebijakan pemerintahan, memberi informasi secara teratur tentang kebijakan, rencana-rencana tentang peraturan dan perundangundangan, dan segala sesuatunya yang berpengaruh kepada kehidupan masyarakat (Ardianto, 2009).

Humas instansi pemerintahan yang memiliki karakteristik yang berbeda dibandingkan humas pada umumnya, membutuhkan dasar hukum yang jelas dalam menjalankan tugas pokok dan fungsinya. Terlebih, efek dari kinerja humas instansi pemerintah sangat luas dan tidak terbatas kepada sekelompok publik tertentu (Wahyu Nilla Sari, 2012). Perbedaan tersebut terletak pada orientasi pelaksanaan pekerjaan yang tidak berusaha memperoeh keuntungan berupa materi tetapi pada kepuasan masyarakat akan kinerja pemerintah. Humas Setda Kota Salatiga juga selalu 
mengerjakan tugasnya sesuai dengan aturan pemerintah yang diberlakukan dan yang telah dituliskan dalam himpunan tugas pokok dan fungsi (tupoksi). Meskipun dalam bagian Humas terbagi menjadi 3 sub-bagian tetapi setiap subbagian selalu bekerja sesuai dengan tugas masing-masing sehingga tidak ada tumpang tindih pekerjaan dan semua tanggung jawab humas dapat dikerjakan dengan baik. Pada gambar 1 dapat dilihat struktur kepegawaian Humas Setda Kota Salatiga.

Dalam perkembangannya, Kota Salatiga mengalami perluasan wilayah dibandingkan dengan pada saat awal dibentuk. Humas sebagai penyampai informasi memiki keterbatasan dalam hal penyebarluasan program kerja pemerintah kepada masyarakat secara menyeluruh sedangkan pemerintah membutuhkan kepercayaan masyarakat sebagai dukungan atas kinerja pemerintah. Di era modern ini sebagai humas modern yang baik akan mendukung kesuksesan perusahaan dimana teknik modern adalah membangun reputasi dan publisitas melalui media massa (Syaifullah, 2004). Humas membutuhkan media massasebagai sarana dalam menyampaikan program kerja pemerintah kepada masyarakat luas secara merata. Selama menjalin hubungan dengan media, diakui oleh seluruh pegawai Humas Setda Kota Salatiga bahwa humas tidak membatasi media apapun yang ingin menjadi partner humas tetapi jurnalis dari media apapun diterima humas tanpa membedakan dengan yang lainnya.

Dalam perkembangannya, Kota Salatiga mengalami perluasan wilayah dibandingkan dengan pada saat awal dibentuk. Humas sebagai penyampai informasi memiki keterbatasan dalam hal penyebarluasan program kerja pemerintah kepada masyarakat secara menyeluruh sedangkan pemerintah membutuhkan kepercayaan masyarakat sebagai dukungan atas kinerja pemerintah. Oleh karena itu, di era modern ini sebagai humas modern yang baik akan mendukung kesuksesan perusahaan dimana teknik modern adalah membangun reputasi dan publisitas melalui media massa (Syaifullah, 2004).

Humas membutuhkan media massasebagai sarana dalam menyampaikan program kerja pemerintah kepada masyarakat luas secara merata. Selama menjalin hubungan dengan media, diakui oleh seluruh pegawai Humas Setda Kota Salatiga bahwa humas tidak membatasi media apapun yang ingin menjadi partner humas tetapi jurnalis dari media apapun diterima humas tanpa membedakan dengan yang lainnya. Humas yang telah memiliki

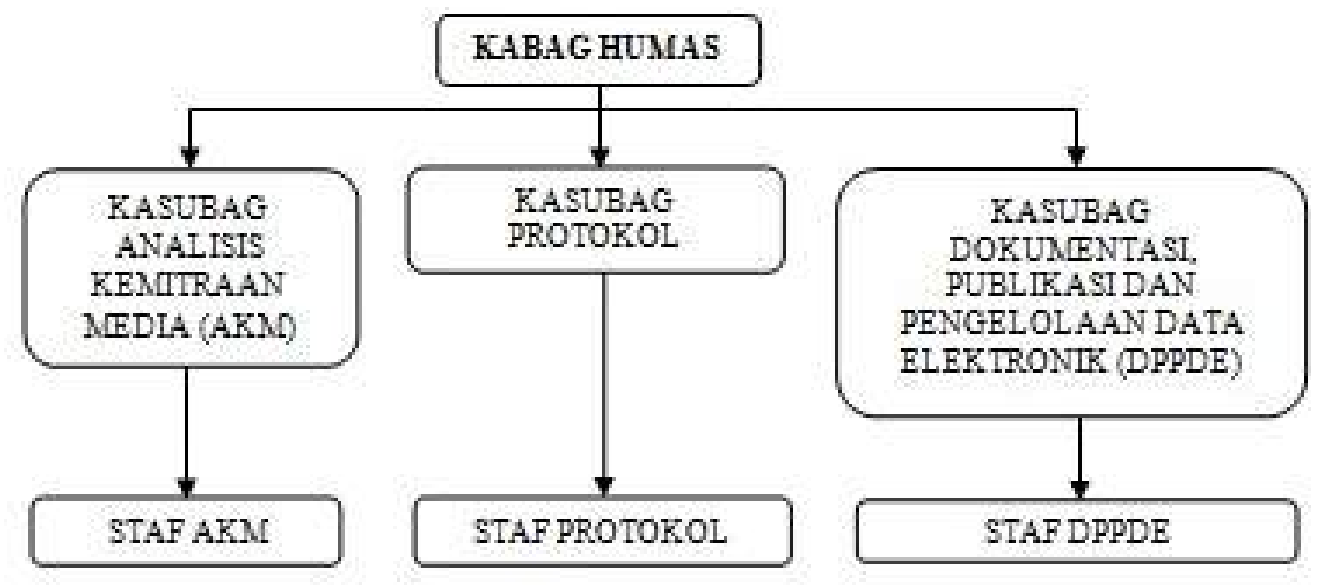

Gambar 1. Struktur Kepegawaian Humas Setda Kota Salatiga 


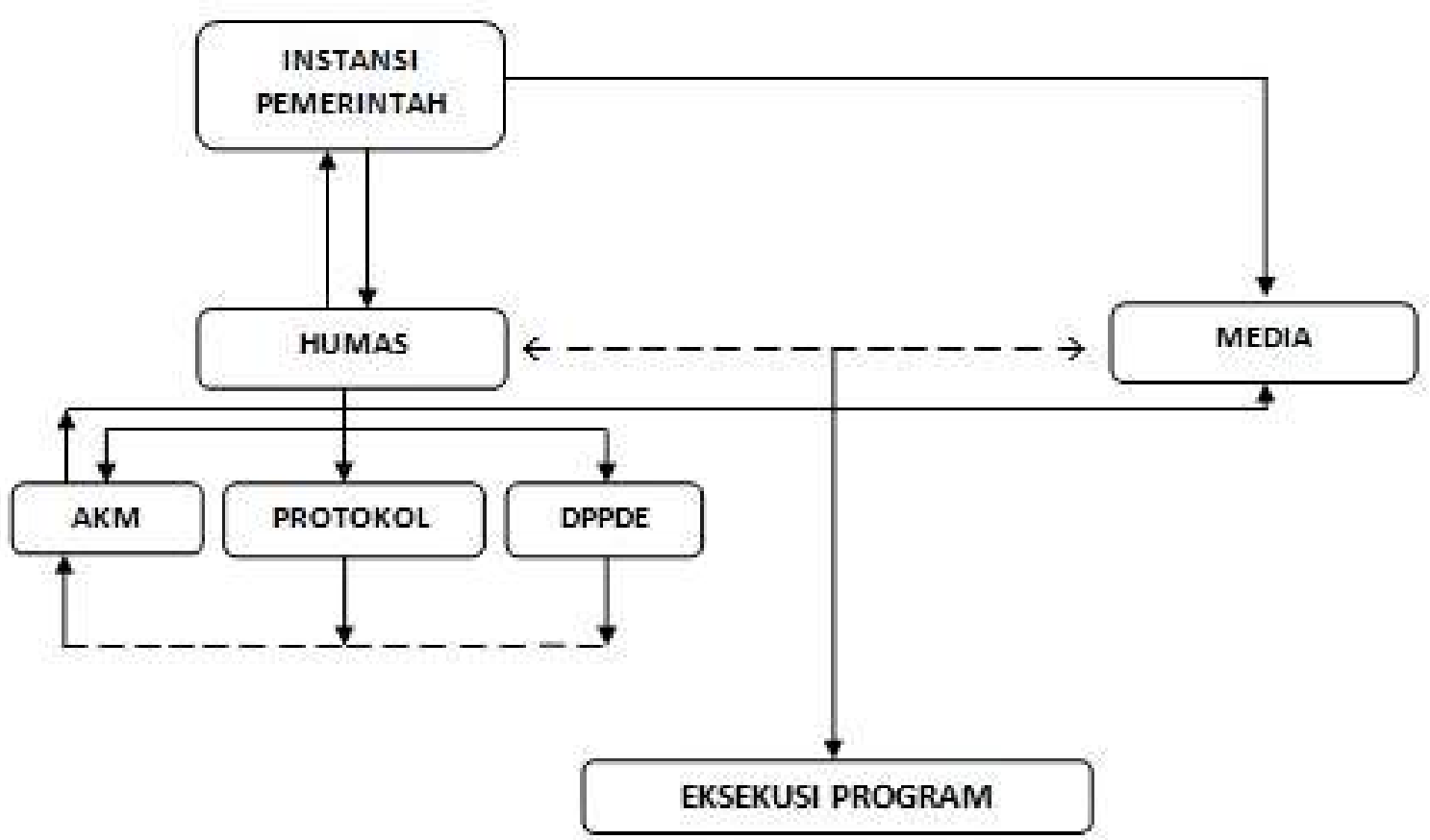

Gambar 2. Jalur Koordinasi Humas dan Media

hubungan baik dengan jurnalis media massa tidak menutup mata tetapi terus mengadakan perubahan dan perbaikan agar hubungan dengan pers yang selama ini tercipta terus terjaga dengan baik (Syaifullah, 2004). Perubahan dan perbaikan tersebut direalisasikan dengan melakukan aktifitas media relations yaitu usaha untuk mencapai publikasi atau penyiaran yang maksimum atas suatu pesan atau informasi humas dalam rangka menciptakan pengetahuan dan pemahaman bagi khalayak dari organisasi atau perusahaan yang bersangkutan (Jefkins, 1992).

Hubungan media terjalin baik secara formal maupun informal. Hubungan baik dapat tercipta juga melalui kegiatan yang humas lakukan. Maksud dari aktifitas media relations dalam hubungan formal adalah hubungan humas dan media dalam suatu kegiatan yang telah menjadi agenda pemerintah dan memiliki anggaran khusus dari pemerintah dalam pelaksanaannya.

Begitu sebaliknya, aktifitas media relations Humas Setda Kota Salatiga dalam hubungan informal yang dimaksud adalah hubungan humas dan media dalam suatu kegiatan yang tidak merupakan agenda rutin pemerintah dan bukan aktifitas yang bersifat resmi serta hanya menggunakan anggaran taktis dalam pelaksanaannya dimana aktifitas yang dilaksanakan biasanya bersifat pribadi.

\section{Aktivitas Media Relations}

Humas Setda Kota Salatiga memiliki bermacam-macam aktivitas, mulai dari jumpa pers, press tour, pembuatan dan pengiriman release, penulisan advertorial sampai aktivitas yang terkait dengan pelatihan-pelatihan. Secara lebih rinci, aktivitas media relations Setda Kota Salatiga itu seperti yang ada di dalam tabel 2

Peran Aktivitas Media Relations dalam Membentuk Berita Positif

Aktivitas media relations yang dilakukan oleh Humas Setda Kota Salatiga, memiliki peran dalam membentuk berita positif terkait dengan kota Salatiga. Peran aktivitas media relation dalam membentuk berita positif itu seperti yang ada pada tabel 3 .

Sesuai dengan batasan masalah penelitian yang dibuat, berikut aktifitas 
Tabel 2. Aktifitas Media Relations Formal - Informal Humas Setda Kota Salatiga

\begin{tabular}{|c|c|c|}
\hline \multicolumn{3}{|c|}{ MEDIA RELATIONS FORMAL (AGENDA PEMERINTAH) } \\
\hline No & Aktivitas & Pelaksanaan \\
\hline 1. & Jumpa Pers & $\begin{array}{l}\text {-Frekuensi : Dilaksanakan setiap bulan hingga } 3 \text { kali } \\
\text {-Tempat : Dimana saja (Di sekitar Salatiga) } \\
\text {-Tujuan : Mendekatkan jurnalis dengan sumber informasi } \\
\text {-Keikutsertaan :Walikota, Narasumber, Jurnalis Media } \\
\text { Kontributor Kota Salatiga, Pegawai Humas } \\
\text {-Agenda : Acara dimulai dengan paparan topik (isu / kegiatan } \\
\text { besar) oleh Kabag Humas, penyampaian materi oleh narasumber, } \\
\text { tanya jawab dari jurnalis kepada narasumber, ramah tamah }\end{array}$ \\
\hline 2. & Press Tour & $\begin{array}{l}\text {-Frekuensi : Dilaksanakan setiap } 1 \text { tahun } 1 \text { kali } \\
\text {-Tempat : Kantor Pemerintahan di luar Salatiga) } \\
\text {-Tujuan : Melakukan studi banding mengenai hubungan humas } \\
\text { dan media di wilayah lain } \\
\text {-Keikutsertan : Walikota, Jurnalis Media Kontributor Kota } \\
\text { Salatiga, Pegawai Humas } \\
\text {-Agenda : Sesampainya di tempat tujuan press tenu dilaksanakan } \\
\text { acara penyambutan oleh pemerintahan yang dikunjungi (Ucapan } \\
\text { selamat datang, pemaparan maksud dan tujuan kehadiran } \\
\text { pemerintah Kota Salatiga kesana, saling berbagi pengalaman } \\
\text { sebagai humas pemerintah, ramah tamah), mengunjungi wilayah } \\
\text { potensial (tempat produksi dan tempat wisata) pada daerah } \\
\text { tujuan press tour dengan didampingi pemerintah disana, acara } \\
\text { penutupan dilakukan dengan pemberian kenang-kenangan dari } \\
\text { kedua belah pihak kemudian dilakukan perjalanan pulang }\end{array}$ \\
\hline 3. & $\begin{array}{c}\text { Pembuatan } \\
\text { dan } \\
\text { Pengiriman } \\
\text { Release }\end{array}$ & $\begin{array}{l}\text {-Frekuensi : Dilaksanakan setiap ada kegiatan yang meminta } \\
\text { protokoler Humas } \\
\text {-Tempat : Di Kantor Humas Setda Kota Salatiga } \\
\text {-Tujuan : Memberikan kejelasan informasi kepada jurnalis saat } \\
\text { tidak dapat ikut hadir dalam suatu kegiatan } \\
\text {-Keikutsertaan : Staff Sub-bagian AKM Humas } \\
\text {-Agenda : Saat kegiatan yang meminta protokoler Humas } \\
\text { dilaksanakan, salah } 1 \text { staff sub-bagian AKM Humas ikut } \\
\text { menghadiri acara untuk meliput acara (mengambil foto kegiatan, } \\
\text { mencari informasi tentang tujuan kegiatan, mewawancarai } \\
\text { beberapa peserta sebagai narasumber berita, mencatat kejadian } \\
\text { penting, membawa berkas kembali ke Kantor Humas dan } \\
\text { membuat laporan kegiatan dalam bentuk release) }\end{array}$ \\
\hline
\end{tabular}

media relations Humas Setda Kota Salatiga selama Mei-September 2014 yang terdiri dari beberapa aktifitas, yang tertuang pada tabel 4 .

Melalui data pada tabel 4. dapat dilihat bahwa aktifitas media relations baik formal maupun informal dilaksanakan olehHumas Setda Kota Salatiga. Hubungan informal yang secara jumlah terlihat lebih sedikit tetapi pada penerapannya dilaksanakan setiap saat melalui komunikasi yang terjalin diantara pegawai humas dan jurnalis media kontributor Kota Salatiga. Hubungan informal yang dimaksud adalah disaat humas selalu menjadikan media sebagai partner dalam setiap kondisi, bukan hanya saat pemerintah membutuhkan publikasi dan pencitraan baik dari media 
Tabel 2.1 Aktifitas Media Relations Formal - Informal Humas Setda Kota Salatiga

\begin{tabular}{|c|c|c|}
\hline \multicolumn{3}{|c|}{ MEDIA RELATIONS FORMAL (AGENDA PEMERINTAH) } \\
\hline No & Aktivitas & Pelaksanaan \\
\hline 4. & $\begin{array}{l}\text { Penulisan } \\
\text { Advertorial }\end{array}$ & $\begin{array}{l}\text {-Frekuensi : Dilaksanakan mengikuti momen } \\
\text {-Tempat : Diutamakan pada surat kabar yang jurnalisnya ada } \\
\text { menjadi kontributor Kota Salatiga dan terlibat aktif dalam } \\
\text { kegiatan Humas Setda Kota Salatiga } \\
\text {-Tujuan: Menyampaikan mengenai bermacam aspek tentang } \\
\text { Kota Salatiga terutama lebih sering mengenai program kerja baru } \\
\text { dari pemerintah kepada masyarakat luas } \\
\text {-Keikutsertaan Staff sub-bagian AKM Humas Setda Kota Salatiga } \\
\text { dan jurnalis surat kabar yang dituju Humas } \\
\text {-Agenda : Sub-bagian AKM menyediakan materi berita, } \\
\text { memberikan materi sesuai topik advertorial kepada jurnalis } \\
\text { untuk membahasakan dengan gaya bahasa advertorial, jumalis } \\
\text { kembali untuk menunjukkan bentuk advertorial yang akan } \\
\text { dimuat, mendiskusikan waktu pemasangan iklan, letak, ukuran } \\
\text { dan anggaran dengan marketing dan selanjutnya masuk proses } \\
\text { pemasangan advertorial pada surat kabar }\end{array}$ \\
\hline 5. & $\begin{array}{l}\text { Pelatihan - } \\
\text { Pelatihan }\end{array}$ & $\begin{array}{l}\text {-Frekuensi : Dilaksanakan sesuai kebutuhan Humas / kebutuhan } \\
\text { masyarakat yang ditangkap Humas dan direalisasikan } \\
\text {-Tempat : Dimana saja (Di sekitar Salatiga) } \\
\text {-Tujuan : Memajukan masyarakat Salatiga \& Mendekatkan } \\
\text { masyarakat dengan pemerintah } \\
\text {-Keikutsertaan : Spenker (Pemerintahan, Jurnalis, Pakar), Staff } \\
\text { Humas (Sub-bagian Protokol \& AKM), Peserta Pelatihan } \\
\text { (Masyarakat, Jurnalis) } \\
\text {-Agenda : Humas menentukan tema, speaker, lokasi dan peserta, } \\
\text { menyiapkan materi pelatihan serta memastikan kelancaran acara }\end{array}$ \\
\hline 6. & $\begin{array}{c}\text { Menyediakan } \\
\text { Kemudahan } \\
\text { Akses } \\
\text { Informasi }\end{array}$ & $\begin{array}{l}\text {-Frekuensi : Dilaksanakan setiap saat ketika jurnalis } \\
\text { membutuhkan informasi } \\
\text {-Tempat : Dimana saja } \\
\text {-Tujuan: Humas sebagai jembatan pemerintah memberikan } \\
\text { informasi kepada jurnalis dan membantu jurnalis menemui } \\
\text { sumber informasi yang bersangkutan } \\
\text {-Keikutsertaan : Jurnalis, Kabag Humas, SKPD, instansi terkait } \\
\text {-A genda : Jurnalis yang membutuhkan informasi baik dari SKPD } \\
\text { maupun bagian selain humas meminta bantuan humas (Kabag } \\
\text { Humas) untuk membantu menemui narasumber yang dituju, jika } \\
\text { humas mengetahui tentang isu tersebut, Kabag Humas memberi } \\
\text { jawab berupa pernyataan sesuai informasi yang jurnalis } \\
\text { butuhkan }\end{array}$ \\
\hline
\end{tabular}

tetapi humas selalu menjalin pendekatan yang berkelanjutan dimana tidak hanya disaat butuh kehadiran wartawan mereka diundang, setelah itu mereka dilupakan (Partao, 2010).
Humas sebagai jembatan dan juru bicara bagi pemerintah juga menyediakan diri untuk menjadi penyambung lidah dari instansi yang memiliki kepentingan dengan media massa. Koordinasi kepada 
Tabel 2.2 Aktifitas Media Relations Formal - Informal Humas Setda Kota Salatiga

\begin{tabular}{|c|c|c|}
\hline \multicolumn{3}{|c|}{ MEDIA RELATIONS INFORMAL (PERSONAL / PRIBADI) } \\
\hline 1. & $\begin{array}{c}\text { Mengundang } \\
\text { pada perayaan } \\
\text { HUT }\end{array}$ & $\begin{array}{l}\text {-Frekuensi : Dilaksanakan setiap kali ada acara peringatan atau } \\
\text { ucapan syukur HUT pegawai Humas } \\
\text {-Tempat : Dimana saja (didalam kantor / diluar kantor) } \\
\text {-Tujuan : Berbagi kebahagiaan dengan jurnalis yang bukan } \\
\text { hanya dianggap sebagai partner kerja tetapi juga saudara } \\
\text {-Keikutsertaan : Pegawai Humas dan Jurnalis } \\
\text {-Agenda : Pegawai Humas yang merayakan HUT } \\
\text { mempersiapkan acara ucapan syukur, mengundang secara } \\
\text { informal rekan kerja Humas dan jurnalis, melakukan prosesi } \\
\text { ucapan syukur dan makan bersama }\end{array}$ \\
\hline 2. & $\begin{array}{c}\text { Silaturahmi } \\
\text { Hari Raya }\end{array}$ & $\begin{array}{l}\text {-Frekuensi : Dilaksanakan setiap Hari Raya keagamaan } \\
\text { berlangsung (Terutama Lebaran karena mayoritas beragama } \\
\text { Islam) } \\
\text {-Tempat : Dimana saja (dikantor, dirumah) } \\
\text {-Tujuan : Memberikan perhatian dan menjalin silaturahmi satu } \\
\text { dengan yang lain } \\
\text {-Keikutsertaan : Pegawai Humas dan Jurnalis } \\
\text {-Agenda : Mcrjelang maupun setelah libur panjang lebaran para } \\
\text { pegawai Humas saling memberikan ucapan selamat Lebaran } \\
\text { serta kepada jurnalis yang ada di press rom. Jika sebelum libur } \\
\text { tidak bertemu, maka diucapkan setelah masuk kerja kembali } \\
\text { setelah libur panjang. Juga memberikan bingkisan hari raya } \\
\text { kepada pegawai humas juga jurnalis. Selain itu, Kabag Humas } \\
\text { yang mengadakan open house mengundang pegawai Humas } \\
\text { beserta jurnalis untuk datang }\end{array}$ \\
\hline 3. & $\begin{array}{c}\text { Perhatian } \\
\text { Khusus Pada } \\
\text { Berkah atau } \\
\text { Musibah }\end{array}$ & $\begin{array}{l}\text {-Frekuensi : Dilaksanakan setiap kali ada berkah yang dirasakan } \\
\text { jurnalis maupun musibah yang tidak pemah direncakan terjadi } \\
\text {-Tempat : Dimana saja } \\
\text {-Tujuan : Menunjukkan rasa perhatian sebagai keluarga besar } \\
\text { Humas yang peduli bukan hanya kepada jurnalis sebagai } \\
\text { individu dalam profesi tetapi juga kepada seluruh keluarga dan } \\
\text { hal-hal diluar pekerjaan } \\
\text {-Keikutsertaan : Pegawai Humas dan Jumalis } \\
\text {-Agenda : Ketika humas mendapatkan undangan (pernikahan, } \\
\text { kelahiran anak), pegawai humas segera mendatangi tempat } \\
\text { (gedung / rumah) untuk hadir berbagi dan menjadi saksi } \\
\text { kebahagiaan, memberikan hadiah (barang / uang) atas nama } \\
\text { Humas. Jika ada yang mengalami musibah (kematian orang } \\
\text { terdekat / kehilangan), pegawia humas segera datang } \\
\text { memberikan ucapan tukut berduka / turut prihatin dengan } \\
\text { musbah yang ada, memberi penghiburan dan dukungan (materi } \\
\text { / moral) }\end{array}$ \\
\hline
\end{tabular}

media bisa dilakukan melalui humas, meskipun ada beberapa instansi yang secara langsung menghubungi media sendiri karena telah kenal dekat dengan jurnalis media.

Hal ini dilakukan sebagai upaya controlling informasi secara lebih mudah jika melalui 1 pintu. Pada gambar 2 disajikan 
Tabel 3. Peran Aktifitas Media Relations Formal - Informal Humas Setda Kota Salatiga dalam Membentuk Berita Positif

\begin{tabular}{lcc}
\hline & \multicolumn{2}{c}{ MEDIA RELATIONS FORMAL (AGENDA PEMERINTAH) } \\
\hline No & Aktivitas & Peran Membentuk Berita Positif \\
\hline
\end{tabular}

1. Jumpa Pers

-Dalam jumpa pers, jurnalis dapat secara langsung bertemu dan mewawancarai narasumber berkaitan dengan topik yang sedang bovming. Hal itu menjadi kesempatan untuk jurnalis dalam membuat berita secara utuh dengan narasumber yang jelas. langsung dapat masuk menjadi muatan berita dan hal itu dapat membentuk berita positif di media cetak.
-Humas juga membantu kelancaran jurnalis untuk dapat sampai ke tempat jumpa pers dengan memberikan uang transportasi kepada jurnalis yang hadir selepas acara diselenggarakan.

Selain berisi mengenai topik yang sedang booming dibicarakan,

-Dalam press tour, jurnalis dapat memperoleh banyak sumber berita dan dapat menggali sedalam-dalamnya judul berita untuk dimuat. Selain keterlibatan langsung jurnalis yang dapat melihat kondisi lapangan sebenarnya, selama press tour dilakukan juga banyak narasumber yang dapat secara langsung ditemui. Selain mengangkat kebudayaan dan keragaman yang ada ditempat tujuan press tour, Humas sebagai wakil pemerintah yang bertindak sebagai panitia kegiatan juga dapat masuk kedalam

2. Press Tour surat kabar dan hal itu menunjukkan kepada masyarakat luas akan adanya program kerja pemerintah yang bermanfaat melalui berita positif di media cetak. Dengan press tour, jurnalis merasa dilibatkan dalam kegiatan pemerintah dan hal ini sedikit banyak mempengaruhi berita yang dimuat di surat kabar dimana berita tersebut akan cenderung positif. -Humas mengeluarkan biaya untuk menanggung uang transportasi, penginapan hingga kebutuhan sehari-hari jumalis yang mengikuti press fener. Diluar biaya akomodasi tersebut, Humas juga memberikan uang saku kepada para jumalis yang terlibat menjadi peserta.

-Releast yang dibuat Humas selalu positif mengenai kegiatankegiatan yang meminta protokoler dari Humas sehingga dalam acara tersebut ada kehadiran Walikota atau yang mewakili. Relense dibuat sebagai upaya membentuk berita positif tentang Pemerintah Kota Salatiga. Melalui release, ketidak beradaan jurnalis di tempat tejadinya suatu kegiatan pemerintah dapat ter-cover dan jurnalis tetap bisa mendapatkan serta

Pembuatan

3. dan

Pengiriman Release mempublikasikan berita karena memang pada dasarnya jurnalis butuh berita dan pemerintah butuh publikasi sehingga samasama saling mendukung. Dengan pembuatan release oleh staff sub-bagian AKM, jurnalis lebih dimudahkan dalam mendapatkan berita. -Release dibuat dengan format berita yang segera dikirimkan ke e-mail jurnalis surat kabar lengkap dengan foto-foto penunjang kegiatan. Jika release dapat dimuat, maka secara langsung berita tentang Pemerintah Kota Salatiga juga dapat terpublikasi dan pastinya unsur berita tersebut adalah positif karena release selalu berisi berita positif. 
Tabel 3.1 Peran Aktifitas Media Relations Formal - Informal Humas Setda Kota Salatiga dalam Membentuk Berita Positif

\begin{tabular}{|c|c|c|}
\hline \multicolumn{3}{|c|}{ MEDLA RELATIONS FORMAL (AGENDA PEMERINTAH) } \\
\hline No & Aktivitas & Peran Membentuk Berita Positif \\
\hline 4. & $\begin{array}{l}\text { Penulisan } \\
\text { Advertorial }\end{array}$ & $\begin{array}{l}\text {-Permintaan penulisan advertorial diberikan humas kepada } \\
\text { jurnalis yang sering terlibat aktif dalam setiap kcgiatan humas } \\
\text { sehingga bisa dikatakan ada kedekatan yang terbangun antara } \\
\text { Humas terutama staff sub-bagian AKM dengan individu } \\
\text { jurnalis. Melalui jurnalis itu pula advertorial dititipkan untuk } \\
\text { diberikan kepada pihak marketing media tempatnya bekerja. } \\
\text {-Dengan melibatkan jurnalis dalam pembuatan advertorial, } \\
\text { maka humas menunjukkan bahwa humas tidak semata-mata } \\
\text { membutuhkan jurnalis demi kebutuhan pemerintah tetapi } \\
\text { humas juga turut berpartisipasi dalam mendukung } \\
\text { keberlangsungan media tempat jurnalis bekerja. Humas yang } \\
\text { melibatkan hubungan antara jurnalis dan Humas menjadi lebih } \\
\text { baik yang nantinya secara tidak langsung akan mempengaruhi } \\
\text { pembuatan advertorial dan bahasa yang digunakan jurnalis } \\
\text { dalam pembuatannya. }\end{array}$ \\
\hline 5. & $\begin{array}{l}\text { Pelatihan - } \\
\text { Pelatihan }\end{array}$ & $\begin{array}{l}\text {-Pelatihan yang dilakukan humas dengan melibatkan jurnalis } \\
\text { media pada saat sebelum acara diselenggarakan yaitu untuk } \\
\text { keperluan publikasi. Selama proses pelatihan hingga akhir acara } \\
\text { humas melibatkan jurnalis baik sebagai pembicara maupun } \\
\text { peserta pelatihan. } \\
\text {-Jurnalis yang juga terlibat aktif dalam acara tersebut (peserta / } \\
\text { spenker), bisa secara langsung membuat acara tersebut menjadi } \\
\text { topik berita dikarenakan keterlibatan langsung dari jumalis } \\
\text { yang dapat secara utuh mengetahui jalannya pelatihan. } \\
\text { Kesempatan un tuk terlibat dalam pelatihan tersebut membuat } \\
\text { jurnalis sedikit banyak mempengaruhi jumalis untuk menulis } \\
\text { berita yang cenderung positif tentang kegiatan tersebut serta } \\
\text { tentang pemerintahar. }\end{array}$ \\
\hline 6. & $\begin{array}{c}\text { Menyediakan } \\
\text { Kemudahan } \\
\text { Akses } \\
\text { Informasi }\end{array}$ & $\begin{array}{l}\text { - Humas terbuka atas jurnalis yang membutuhkan informasi } \\
\text { baik dari SKPD maupun instansi lain ataupun Humas (Kabag } \\
\text { Humas) sendiri. } \\
\text {-Kemudahan akses informasi menjadikan jurnalis dapat secara } \\
\text { langsung mendapatkan klarifikasi kasus dari pihak yang tepat } \\
\text { sehingga berita dapat berimbang dengan adanya kejelasan dan } \\
\text { klarifikasi berita dan dengan ini dapat membentuk berita yang } \\
\text { mengaburkan unsur negatif. }\end{array}$ \\
\hline 7. & $\begin{array}{c}\text { Mengundang } \\
\text { Jurnalis Dalam } \\
\text { Acara } \\
\text { Pemerintah }\end{array}$ & $\begin{array}{l}\text {-Humas selalu mengundang jurnalis untuk dapat hadir secara } \\
\text { langsung pada kegiatan pemerintah dan meliput berita tentang } \\
\text { suatu kegiatan tertentu. Dalam kegiatan tersebut, jurnalis dapat } \\
\text { meliput sesuai dengan temuan dilapangan dan dapat secara } \\
\text { langsung bertanya pada narasumber yang diperlukan untuk } \\
\text { membuat suatu berita. } \\
\text {-Kedekatan antara humas dan jurnalis juga antara jurnalis } \\
\text { dengan pegawai pemerintah bagian lain membuat } \\
\text { pengumpulan data berita dapat berjalan dengan mudah dan } \\
\text { sangat menguntungkan jurnalis dalam membuat berita positif } \\
\text { tentang Pemerintah Kota Salatiga. }\end{array}$ \\
\hline
\end{tabular}


Tabel 3.2 Peran Aktifitas Media Relations Formal - Informal Humas Setda Kota Salatiga dalam Membentuk Berita Positif

\begin{tabular}{|c|c|c|}
\hline \multicolumn{3}{|c|}{ MEDLA RELATIONS INFORMAL (PERSONAL / PRIBADI) } \\
\hline No & Aktivitas & Pelaksanaan \\
\hline 1. & $\begin{array}{c}\text { Mengundang } \\
\text { pada perayaan } \\
\text { HUT }\end{array}$ & $\begin{array}{l}\text {-Kedekatan dapat dibangun dengan melaksanakan aktivitas } \\
\text { media relations pada ranah informal. Dengan mengundang } \\
\text { jurnalis pada perayaan HUT akan tumbuh rasa saling memiliki } \\
\text { dan dihargai, hal itulah yang membentuk ikatan emosional } \\
\text { antara humas dan jurnalis yang sedikit banyak mempengaruhi } \\
\text { keputusan jurnalis dalam membuat suatu berita tentang } \\
\text { Salatiga dan pemerintahan didalamnya. }\end{array}$ \\
\hline 2. & $\begin{array}{l}\text { Silaturahmi } \\
\text { Hari Raya }\end{array}$ & $\begin{array}{l}\text {-Perhatian pada perayaan Hari Raya juga tidak luput dari } \\
\text { pandangan Humas untuk menjalin tali silaturahmi dimana hal } \\
\text { tersebut dapat membentuk ikatan emosional. Silaturahmi hari } \\
\text { raya juga membuktikan bahwa Humas menghormati adanya } \\
\text { hari besar keagamaan dan kepercayaan yang dianut oleh } \\
\text { masing-masing jurnalis. Silaturahmi juga dapat mempererat } \\
\text { institusi pemerintah dengan jurnalis. Hal demikian secara tidak } \\
\text { langsung mempengaruhi pemberitaan yang dibuat oleh jurnalis. } \\
\text { Keterlibatan jurnalis secara langsung dalam acara silaturahmi } \\
\text { dapat menjadi bahan berita yang dibuat oleh jurnalis sendiri dan } \\
\text { berita tersebut cenderung positif dikarenakan jurnalis ada dalam } \\
\text { acara ini. }\end{array}$ \\
\hline 3. & $\begin{array}{c}\text { Perhatian } \\
\text { Khusus Pada } \\
\text { Berkah atau } \\
\text { Musibah }\end{array}$ & $\begin{array}{l}\text {-Tak jauh berbeda dengan wujud perhatian yang diberikan } \\
\text { humas kepada jumalis dalam dua kegiatan informal lainnya, } \\
\text { perhatian pada berkah dan musibah yang dialami jurnalis juga } \\
\text { membuktikan adanya perhatian yang tulus dari humas yang } \\
\text { tidak hanya mencari jurnalis dan berusaha berbuat baik saat } \\
\text { humas membutuhkan pemberitaan. Dengan demikian, rasa } \\
\text { saling percaya dan membutuhkan yang tumbuh antara humas } \\
\text { dan jurnalis juga berperan dalam membawa jumalis menuliskan } \\
\text { berita-berita tenntang Salatiga dengan bahasa yang positif. }\end{array}$ \\
\hline
\end{tabular}

bagan jalur koordinasi yang tercipta ketika instansi lain membutuhkan keterlibatan media melalui humas ataupun dari subbagian humas sendiri.

Dari gambar 2. dijelaskan bahwa Humas Setda Kota Salatiga yang terbagi menjadi 3 sub-bagian, membentuk koordinasi melalui satu pintu yaitu melalui sub-bagian Analisis Kemitraan Media (AKM) ketika membutuhkan jurnalis dalam suatu kegiatan. AKM adalah subbagian yang secara langsung berhubungan dengan media sesuai dengan tugas pokok dan fungsi (tupoksi) yang tertulis. Dengan perkembangan teknologi, cara yang digunakan humas dalam melakukan koordinasi dengan media semakin variatif dan fleksibel serta tidak terbatas dengan ruang ataupun harus tatap muka dengan jurnalis. Melalui jumpa pers, koordinasi bisa dilakukan juga melalui short message service (sms), telepon maupun media sosial.

Setelah mengetahui macam aktifitas media relations yang dilaksanakan Humas Setda Kota Salatiga dengan melibatkan jurnalis media cetak dan mengetahui peran masing-masing aktifitas dalam membentuk berita positif, diketahui bahwa beberapa aktifitas media relations formal memberikan kesempatan kepada jurnalis 
Tabel 4. Aktivitas Media Relations Humas Setda Kota Salatiga Mei-September 2014

\begin{tabular}{ccc}
\hline No & Aktivitas & Kategori \\
\hline 1 & Press Tour & Formal \\
2 & Protokoler Acara TMMD & Formal \\
3 & Acara Prokasih & Formal \\
4 & HUT Radio Suara Salatiga & Formal \\
5 & HUT Kabag Humas & Informal \\
6 & Protokoler Hari Jadi Salatiga & Formal \\
7 & Halal Bihalal Lebaran di Rumah Kabag Humas & Informal \\
8 & Jumpa Pers untuk Acara SMAC & Formal \\
9 & Aqiqoh Anak Staf Humas, Sub-bagian Protokol & Informal \\
10 & Pembuatan dan Pengiriman Release & Formal \\
11 & Acara SMAC & Formal \\
& &
\end{tabular}

untuk membuat berita secara langsung dengan menemui narasumber yang ada seperti jumpa pers, press tour, pelatihanpelatihan, menyediakan kemudahan akses informasi dan mengundang jurnalis dalam acara pemerintah. Tetapi, aktifitas media relations informal memliki peranan lebih banyak dibandingkan dengan aktifitas formal dalam membentuk beritapositif dikarenakan aktifitas informal dapat membentuk hubungan baik secara personal.

Dengan hubungan baik yang terbentuk melalui aktifitas media relations membuat usaha Humas dalam membentuk berita positif melalui release selalu dimuat di media cetak. Release yang dibuat humas selalu berisi berita positif sehingga ketika dimuat pada surat kabar, secara langsung dapat menyuguhkan berita positif tentang pemerintah kepada masyarakat. Release dibuat juga sebagai upaya meminimalisir berita-berita negatif dikarenakan kurang pahamnya jurnalis akan kejadian sebenarnya.

Mengenaiisunegatifyangmenjadifakta pemerintah, jurnalis memberitahukannya kepada humas bahkan ketika humas belum mendengar isu tersebut, dan meskipun ada berita negatif namun selalu berimbang dengan menuliskan isi klarifikasi pihak pemerintah terhadap suatu berita negatif tertentu serta bahasa yang digunakan jurnalis tidak mendiskreditkan humas dan instansi pemerintah. Hal itu dikarenakan adanya kedekatan emosional antara humas dan jurnalis serta didukung dengan adanya kedekatan ruang kerja diantara keduanya. Humas menyediakan ruang kerja bagij urnalis yang disebut dengan press room yang memudahkan adanya konfirmasi dan klarifikasi dari pihak Humas kepada jurnalis ketika jurnalis menemui isu negatif tentang pemerintah. Dalam menjalankan tugasnya, jurnalis media tetap menjalankan tanggung jawab pekerjaan sesuai kode etik yang dimiliki tetapi kendali lainnya adalah aspek moral individu yang tetap dimiliki jurnalis sebagai kendali pertama dalam kebebasan pers yang artinya apakah memiliki cukup moral untuk menulis sesuatu yang berhubungan dengan hati nurani (Abdullah, 2004).

\section{Simpulan}

Aktifvtas media relations Humas Setda Kota Salatiga dengan jurnalis media kontributor Kota Salatiga telah menciptakan hubungan baik di antara keduanya dalam ranah formal maupun informal. Peran aktifitas media relations yang dilakukan humas dalam ranah formal mampu memberikan ruangkepada 
jurnalis untuk terlibat secara langsung dalam kegiatan pemerintah dan bertemu dengan narasumber yang tepat sehingga informasi yang didapat sebagaiisi berita dapat dengan jelas disampaikan dikarenakan berasal dari orang yang tepat. Sedangkan kegiatanmedia relations informal berperan membentuk kedekatan emosional dan menciptakan hubungan baik antara humas dan media, rasa saling pecaya serta menjaga satu sama lain.

Kedekatan inilah yang membuat berita positif mengenai pemerintah dapat terbentuk seperti halnya ketika humas mengirimkan release tentang setiap kegiatan pemerintah yang selalu berisi positif kepada jurnalis media cetak terutama surat kabar yang memiliki halaman khusus untuk Kota Salatiga. Hubungan baik yang telah terjalin melalui aktifitas media relations, menjadikan jurnalis selalu berupaya memuat release yang dikirimkan humas meskipun terkadang perlu melalui tahap editing terlebih dahulu.

Dalam menemui isu negatif, kedekatan emosional dan hubungan baik yang tercipta antara humas dan media membuat jurnalis justru selalu menyampaikan isu tersebut kepada bagian humas bahkan ketika humas sendiri belum mendengar adanya isu negatif tersebut, yang disampaikan dengan penyampaian informal. Kedekatan antara humas dan media yang terbentuk melalui pelaksanaan aktifitas media relations telah membawa jurnalis memberikan kesempatan untuk humas mengklarifikasi berita negatif tersebut lebih dulu dan memasukkan klarifikasi itu kedalam kemasan berita sehingga berita tetap terbentuk dan dipublikasikan tetapi tidak mendiskreditkan keberadaan humas dan pemerintah dan berimbang.

Implikasi dari penelitian ini bahwa aktifitas media relations sangat diperlukan oleh setiap instansi pemerintah. Media relations memberikan kontribusi positif untuk peningkatan hubungan baik antara masyarakat dan pemerintah.

\section{Daftar Pustaka}

Abdullah, Aceng(2004).Press Relations Kiat Berhubungan Dengan Media Massa, Bandung: PT Remaja Rosdakarya.

Ardianto, Elvinaro(2009).Public Relations Pendekatan Praktis untuk menjadi Komunikator, Orator, Presenter dan Juru Kampanye Handal, Bandung: Widya Padjadjaran

(2010). Metodologi Penelitian untuk Public Relations Kuantitatif dan Kualitatif, Bandung: Simbiosa Rekatama Media

Bungin, Burhan (2010).Penelitian Kualitatif Komunikasi Ekonomi, Kebijakan Publik Dan Ilmu Sosial Lainnya, Jakarta: Kencana Prenada Media Group.

Darmastuti, Rini(2012).Media Relations - Konsep, Strategi, dan Aplikasi, Yogyakarta: Penerbit ANDI

Iriantara, Yosal (2005).Media Relations Konsep, Pendekatan, Dan Praktik, Bandung: Simbiosa Rekatama Media

Jefkins, Frank (1992). Public Relations, Jakarta: Penerbit Erlangga

Kasali, Rhenald (2003).Manajemen Public Relations, Jakarta: Grafiti.

Mursito BM. (2013).Jurnalisme Komprehensif: Konsep, Kaidah, \& Teknik Penulisan Berita, Feature, Artikel., Jakarta: Literate.

Mantra Bagoes, Ida(2004).Penelitian Kualitatif, Jakarta: PT. Gelora Aksara Pertama.

Prasetyo, Budi (2010). Strategi Media Relations Dalam Pemerintahan Daerah (Studi Deskriptif Kualitatif tentang Strategi Media Relations Bagian Humas dan Protokol Pemerintah Kota Surakarta 
dalam Menjalin Hubungan dengan Media Untuk Meningkatkan Citra Positif di Masyarakat Kota Surakarta, Solo: Universitas Sebelas Maret (UNS).

Partao, Zainal Abidin(2010).Media Relations, Strategi Meraih Dukungan Publik, Jurnal Komunikologi 7 : 1, http://www. esaunggul.ac.id, Diakses Pada 6 Mei 2015 Pukul 20.00 WIB.

Syaiffulah, Nurudin Muhammad (2004). Media Relations - Panduan Praktis Praktisi Public Relations, Malang: Cespus.

Suparno, Paul(2008).Action Research: Riset Tindakan untuk Pendidik, Jakarta: PT. Grasindo, Anggota Ikapi.
Thomsett, Rob (2006).Radical Project Management, Jakarta: PT. Gelora Aksara Pratama.

Wahyu Nila Sari, Betty (2012). Humas Pemerintah, Yogyakarta: Graha Ilmu.

Yunita, Elsya (2012). Pelaksanaan Media Relations di Lembaga Pemerintahan Dari Sudut Pandang Praktisi Humas Kementerian dan Wartawan (Studi Kasus : Media relations di Kementerian Pendidikan dan Kebudayaan Republik Indonesia dalam rangka sosialisasi program dan kebijakan kementerian), Jakarta: Universitas Indonesia (UI). 